\title{
THE INFLUENCE OF GOVERMENTAL MANAGEMENT, CUSTOMERS AND SUPPLIERS RELATIONSHIP TO FOREIGN DIRECT INVESTMENT COMPANIES' PERFORMANCE IN BINH DUONG PROVINCE: A QUALITATIVE STUDY
}

\author{
Nguyen Van Phuong ${ }^{1, *}$, Nguyen Dinh Khoi ${ }^{2}$, Nguyen Thi Hong $\mathrm{An}^{3}$ \\ ${ }^{1,2,3}$ International University, Vietnam National University HCMC. \\ *Email: nvphuong@hcmiu.edu.vn
}

(Received: April 02, 2016; Revised: April 19, 2016; Accepted: May 17, 2016)

\begin{abstract}
Binh Duong province is becoming one of the most attractive locations for Foreign Direct Investment (FDI) firms of different origins, yet few studies have been conducted to investigate the several aspects related to FDI firms in Binh Duong. This research aims to evaluate the performance of FDI companies and understand the potential determinants of the performances by utilizing the exploratory approach. The research methodology is carefully designed to ensure the trustworthiness in data collection, coding and analysis. The study finds out four dimensions of Governmental Management: Managerial Political Ties, Institutional Support, Governmental Training Activities and Administrative Procedure that relate to FDI firm performance and competitive advantages. Furthermore, relationship with customers and suppliers manifest correlations with the performance and competitive advantage of FDI enterprises. Finally, this paper suggests some managerial implications for the governmental agencies to improve the current policies to attract more foreign investors. Specifically, FDI companies also get some valuable information when investing in the emerging market like Vietnam in general and Binh Duong province in particular.
\end{abstract}

Keywords: FDI; Governmental Management; Customer Relationship; Supplier Relationship; Firm's performance.

\section{Introduction}

\subsection{Overview of foreign investment in} Vietnam

As the world economy is recovering status after the recent crisis, the developing markets are currently attractive to investors from all over the world. A research of A.T. Kearney, the international consulting company, demonstrated that in the emerging world, besides the leading country in attracting foreign investment such as China, Brazil, Thailand, Indonesia, Malaysia, Vietnam started to attract new investment in these years. With low labor cost, these countries have attracted FDI inflows in labor-intensive industries.

Foreign Direct Investment (FDI) has contributed to the economic growth of Vietnam through the enormous benefits. Firstly, job opportunities for workers as well as demand for new technologies and know-how have been fulfilled. According to the statistics of the General Statistic Office of Vietnam, FDI has contributed $20 \%$ to the GDP of Vietnam, along with the technological transfers, the 
advances in managerial method, and the increase in the production capacity (General Statistics Office (GSO), 2014). The benefits helped Vietnam with the opening and integration into the region and the world economy. On top of that, FDI has helped to stimulate technological investment of domestic firms so that they can enhance the product quality to survive in a fierce competition of the market.

Secondly, the attraction of FDI has contributed significantly to the total export of Vietnam and accounted for approximately $50 \%$ of the total export (GSO, 2014). The remarkable achievement has eventually become more opportunities for constituting the improvement in the labor market. With the important role of FDI enterprises in the Vietnamese economy, improving management efficiency and attracting foreign capital is an essential task of the authorities of both central and provincial levels.

\subsection{Foreign Investment in Binh Duong Province}

With the share of $63 \%$ in the economic structure and the production value of over 105,000 billion VND annually, Binh Duong is becoming one of the attractive destinations with the highest growth rate of Vietnam (Binh Duong Statistic Office, 2014). According to Foreign Investment Agency, Ministry of Planning and Investment, Binh Duong has attracted 2,731 FDI projects with registered capital of more than US\$ 24 billion. Thus, Binh Duong has become one of the top four provinces for FDI attracted projects and capital investment.

There are 28 industrial zones and 8 industrial districts that are currently operating. The establishment of these industrial zones facilitates the escalation of foreign investment into the areas. Additionally, there is a considerable diversity in the economic sectors and the areas of investment as well. The industries range from manufacturing (agricultural and forestry products, textiles, leather and footwear, steel, paint, electrical and electronic products, and chemical products), construction, real estate activities, wholesales and retails, repair of motor vehicles and motorcycle. Remarkably, the manufacture industry has gotten 2,412 of the total 2,615 projects in Binh Duong province at the end of 2014 (Binh Duong Statistic Office, 2014).

Recently, Taiwan has accounted for the most projects as well as the largest amount of capital invested in Binh Duong province. At the end of 2014, Taiwan had 799 projects with the total capital amounted to US\$ 4,268 million. Meanwhile, Japan had approximately a third of Taiwanese total projects, but the total capital amounted up to US\$ 4,173 million (Binh Duong Statistic Office, 2014). The other countries that also constitute a large portion of foreign investment in Binh Duong province are Korea, Singapore, Hong Kong and Malaysia.

The data from the report of the Binh Duong Industrial Zones Authority has also shown that in 2015, Binh Duong has attracted US\$ 339 million FDI, an increase of $6.58 \%$ from 2014. Particularly, there are 46 new projects with the registered capital of US\$ 235 million. Compared to 2014, FDI companies increased $24.32 \%$ in terms of licensed projects and $15.55 \%$ in terms of registered capital.

Given the role of FDI in the Vietnamese economy and the explosive growth of the FDI in Binh Duong province, the research broadly focuses on clarifying the determinants of FDI business performance. In fact, the governmental management played a key role in the efficiency of FDI firm performances. Thus, this qualitative study initially aims to explore the activities of the provincial government and investigate its impact on the performance of FDI firms. The findings will provide invaluable feedbacks of foreigners to the governmental agencies to improve the 
public administration regulations and attract more foreign investment projects. The results would also be helpful for current and potential foreign investors to understand the investment environment and regulations when investing and operating in Binh Duong province.

\section{Review of relevant literatures}

2.1 Literature on Governmental Management, Customers' and Suppliers' Relationship

2.1.1. Literature on Governmental Management

The prior studies only focused on exploring the relationship between firm performance and government agencies. Particularly, some studies considered the intrinsic ability of the enterprises to determine whether external and internal factors are playing an important role in the business activities. Leading research in this field, Li \& Zhang (2007) investigated the influences of managerial resources (political relations and professional experience) to Chinese new business projects in high-tech industries. They illustrated that both types of resource management have positive impacts on the effectiveness of modern high-tech business performances.

Additionally, Li et al., (2008) focused on exploring the relationship of the ruling Communist Party of China on the operations of private companies. After analyzing a nationwide survey of private companies in China, the authors found that the Party's members working in private enterprises have positive effects on the firm performance. In addition, the party members also help private enterprises to get loans from either commercial banks or other governmental institutions, and to catch business opportunities in the immature legal system. Finally, those members played a crucial role to help managers to run their business effectively, especially when they are operating in the poorly organized market.

Also interested in the high-tech field in
China, Sheng et al. (2011) deeply investigated the firm performance of operating in this sector not only through a large-scale survey of 500 companies but also through intensive interviews of 50 managers. The survey questions and interviews mainly focus on relevant issues such as firm performance, business relationship, political ties, technological changes, unstable demand, ineffective law enforcement and support from the government. As a result, they suggest that managers in China should create business relationships and political connections to explore business opportunities in China.

The most recent study, Gou et al. (2014) focused on the role of mediating factors affecting the relationship between political ties and firm performance in China. The mediating elements were the support of institution, organizational legitimacy, organization's opportunity recognition. They found out that the legitimacy had no impact on political relationship and the business performance, although businesses have to follow the political ties to strengthen the legitimacy of the firm.

Overall, previous studies focused on investigating how government agencies affect the level of competition and firm performance. The impact is described to be different according to the size and investment capital of the enterprises. However, the above studies do not deeply explore the roles of governmental management and the effectiveness of those aspects as governmental management is a broad and vague construct to stand alone. Even worse, there is a little study on the governmental ties in the context of Vietnam.

\subsubsection{Customer and Supplier} Relationship Management

Customer and Supplier relationship management have been considered as facilitators of a firm performance. With respect to Supplier Relationship management, 
the concept has been broadly focused on as part of the Supply chain process in a large body of literature (Saraph et al., 1989; Flynn et al., 1994, Flynn et al., 1995; Ahire et al., 1996; Black and Porter; 1996). In general, these studies have not defined clear measurement scales for constructing this relationship. Kannan and Choon Tan (2006) established and validated the Buyer-Supplier Engagement constructs to investigate the supplier relationship and firm performance. They found there was a strongly positive effect of Buyer-Supplier Engagement on the Success of Buyer-Supplier Relationship, and then transferring to the firm performance.

The previous studies have not concerned about the direct impact of Supplier Relationship on firm performances. Even worse, the definition of the supplier relationship is vague, not to mention the shortage of measuring approaches in different contexts. Thus, this qualitative study aims to identify the measurement scale of supplier relationship in the Vietnamese context, and then develop our conceptual framework.

Unlike the supplier relationship, the customer relationship is a well-established construct, emphasized in several prior researches. Soch and Sandhu (2008) showed the strong relationship between customer relationship management (CRM) and financial performance of Indian firms. In another study, Ernst et al., (2010) explored the CRM in a different context with the involvement of new products. As a result, they also confirmed the strong relationship of CRM with firm performances. However, Reimann et al. (2011) tested the effect of CRM under different mediators (differentiation and cost leadership). The result was surprising in that no direct effect of CRM was found. Rather, the relationship was fully mediated by differentiation and cost leadership. Besides, Coltman et al. (2011) also conducted a research to formulate and test the relationship between CRM and firm performances and find out the strong linkage. In addition, the study also invested the antecedences of CRM, named the lower firm capabilities. The influences of Human Analytics and Business Architecture were justified, whereas the impact of IT Infrastructure was found to be mediated by Human Analytics and Business Architecture.

Although a large body of studies has been carried out to investigate the problems related to the importance of managing customer relationships, there are two main gaps in previous studies worth addressing. Firstly, most preceding study developed a formative construct of CRM, which is reported to be inconsistent through different circumstances. Secondly, there is a little study combining CRM with the case of FDI firms. Given the increasing number of FDI firms in the Vietnam's emerging market, especially in Binh Duong province, the gaps need to be fulfilled.

\subsection{Study on Foreign Direct Investment in Vietnam}

The empirical literature concerning FDI in Vietnam could be classified into three main streams. The first category concentrated on the impact of FDI companies on macroeconomic perspectives in terms of economic growth in provincial or national levels (Su Dinh Thanh \& Nguyen Minh Tien, 2014; Pham Thi Hoang Anh \& Le Hoai Thu, 2014; Pham The Anh \& Nguyen Thi Hong Dao, 2013). Moreover, another group of studies focused on how to attract FDI inflows in terms of marketing strategies, including tax exemption and improvement investment environment, such as the improvement of provincial competitiveness index (Nguyen Quoc Nghi \& Nguyen Huu Thuan, 2012; Hoang Cuu Long, 2009).

Lastly, some prior studies investigated the issues of transfer pricing. In other words, some FDI companies attempt to avoid income 
tax by transferring transaction costs among their subsidiaries (Ha Nam Khanh Giao \& Bui Le Ha, 2009; Nguyen Minh Ha \& Bui Quan Trong, 2013).

Generally, through the literature review, we have identified several gaps of previous studies that this paper needs to fulfill such as confirming the governmental ties, constructing the reliable measurement scales for Supplier and Customer Relationship Management, and establishing the conceptual framework for a further quantitative test.

\section{Methodology}

\subsection{Sampling and targeted correspondents}

The study conducted 24 in-depth interviews with Chief Executive Officers or General Directors of FDI enterprises and 11 in-depth interviews with experts and government officials in Binh Duong province. Initially, we developed a list of potential questions based on dimensions in the literature review to conduct five first interviews, and then the questionnaire was modified according to the correspondents' comments and the real environment context of attractive policies of Binh Duong province. Specifically, the study also includes the exploratory approach to discover new latent variables through the in-depth interviews given the distinctive features in the public policies to attract FDI companies in Binh Duong province.

Theoretical sampling collection is followed by the standard qualitative studies (Strauss \& Corbin, 1990; Mello \& Flint, 2009). Remarkably, after conducting 35 the interviews, we identified the potential linkages among objective factors, which were confirmed by both enterprises and government agencies to establish the conceptual framework. Particularly, after identifying relevant problems and feedbacks of FDI companies relating to the public administration, we quickly turned to the government agencies to cross-check and confirm the problems and figure out the possible solutions.

In each interview, semi-structured type is employed to make use of the developed questions as well as to generate and maintain further discussions in the related fields. The method is reliable in that it created basic understandings of the topic between interviewers and correspondents and enabled findings with higher consistency and relevance (Cheung et al., 2010). The method also allowed for findings with additional information (Miles \& Huberman, 1994). The time for each interview is ranging from 1-2 hours, allowing interviewees to feel more comfortable, thus providing reliable information.

Table 1 summarizes the company information. It is worth noting that we have to guarantee with interviewees without releasing their names, positions as well as the company name. Therefore, we are only able to provide basic information as below. Thanks to the large number of FDI firms in these industries in Binh Duong including 2,412 in manufacturing industries and 49 in distribution, wholesale and retail industries (Binh Duong Statistics Office, 2014), Table 1 summarizes general information, which does not reveal the identity of the interviewed companies. 
Table 1. Information of companies participating in the study

\begin{tabular}{|c|c|c|}
\hline No. & Industry & Country \\
\hline 1 & Textile (Plush manufacture) & Korea \\
\hline 2 & $\begin{array}{l}\text { Supporting industry (Adhesive } \\
\text { manufacture) }\end{array}$ & Japan \\
\hline 3 & Food Processing & Taiwan \\
\hline 4 & Textile and Shoe Manufacture & Taiwan \\
\hline 5 & Household furniture & Taiwan \\
\hline 6 & Textile & Korea \\
\hline 7 & Textile & Korea \\
\hline 8 & Textile & Taiwan \\
\hline 9 & $\begin{array}{l}\text { Component of Automobile and } \\
\text { Electronic device }\end{array}$ & Japan \\
\hline 10 & Plastic process & Japan \\
\hline 11 & $\begin{array}{l}\text { Supporting industry (Adhesive } \\
\text { Manufacture) }\end{array}$ & Japan \\
\hline 12 & Textile and Shoes Manufacture & Taiwan and Thailand \\
\hline 13 & Chemical manufacture & Japan \\
\hline 14 & Paper manufacture & Japan \\
\hline 15 & Fodder manufacture & Taiwan \\
\hline 16 & Electric component manufacture & England \\
\hline 17 & Steel Manufacture & Joint Venture \\
\hline 18 & Industrial Equipment Manufacture & Korea \\
\hline 19 & Cosmetics Manufacture & Korea \\
\hline 20 & Consumer Goods Manufacture & Joint Venture \\
\hline 21 & American Car Distribution center & Joint Venture \\
\hline 22 & Japanese Car Distribution center & Joint Venture \\
\hline 23 & Industrial Zones & Joint Venture \\
\hline 24 & $\begin{array}{l}\text { Electronic Components } \\
\text { Manufacture }\end{array}$ & Japan \\
\hline
\end{tabular}

\subsection{Data Coding and Analysis}

Firstly, the collected information is coded through a three-step procedure as recommended by Strauss' well-established grounded theory for coding data: open coding, axial coding and selective coding (Strauss, 1987; Strauss \&
Corbin, 1990). The records of the interview are reexamined to make the transcript, which is then analyzed thoroughly. During the first step, open coding, the transcript is broken down into items, and the items are grouped into different categories according to their 
conceptual contents. After the independent categorization, we hold several meetings to discuss and filter the categories. The process of individual works followed by group work is utilized not only to ensure the consistency in the coding process but also to verify the categories created by each member (Gligor \& Autry, 2012). There are 40 codes after the open coding. The codes is gone through a comprehensive comparative analysis, as suggested by the grounded theory methodology (Strauss \& Corbin, 1990). In this stage, the shattered data were compared and grouped into different categories based on the contents. The categories are defined and given names in line with the literature reviews and the current context of the industrial characteristics in Binh Duong province.

Subsequently, axial coding is performed to generate better explanations for the categories from the open coding. According to Gligor \& Autry (2012), the purpose of axial coding is to rearrange the fractured data in the open coding stage (Gligor \& Autry, 2012). We link the categories together in order to give them definition and to form welldeveloped dimensions. Finally, selective coding is employed to filter out the irrelevant categories and relationships. Only variables that are related to the study as well as their relationship are kept.

\section{Result presentation}

\subsection{Firm performance}

The first dependent factor, as predicted by the research team is a firm performance. The overall performance of any companies is the main indicator of growth in the companies. Thus, it is no doubt that the interviewed firms paid special attention to it. They described the positive link between the firm performance and other independent constructs such as the elements of governmental management, customers' and suppliers' relationship management. However, in some dimensions of governmental management, such as the
Institutional Support and Administrative Procedure, the companies pointed out the negative correlation of the poor supports and complex procedures and the efficiency of business performances. It can be logically inferred that the advances of these areas will definitely improve FDI firm performance to different extents.

The positive influences can be described as the growth in profits, sales and market shares thanks to the strong ties with political officials facilitating companies' process and the good relationships with customers. Other effects are better quality, higher productivity, and sustainable development with the help of main suppliers.

\subsection{Competitive Advantage}

Through the axial coding, the study includes another dependent construct called competitive advantage, which is described through the term of products with high quality materials and competitive cost, distinctive marketing campaigns, product customization in accordance with the growing demand, and production of high efficiency. All participants have discussed and given the same opinions. Through different approaches, they agreed that it is crucial to establish a strong relationship with customers as well as political officials of various levels. Consensually speaking, the government agencies at all levels should continue removing the administration barriers and bureaucratic styles and inefficiency. In addition, customer-oriented approaches are important in gaining the advantages. More knowledge about whom we are serving will guide us to have better strategies in the future.

\subsection{Governmental Management}

All participants confirmed that they have received many supports from the Binh Duong Industrial Zones Authority. This enables Binh Duong to attract many FDI projects and gain competitive advantage. The content of the interview consisting of four categories, all of 
which are independent and multidimensional factors. The four emergent constructs are Managerial Political Ties, Institutional Support, Training Activities, and Administrative Procedures.

\subsubsection{Construct 1: Managerial Political Ties}

The first emerged dimension is Managerial Political Ties, which is defined as the relationship with other leaders and managers at different management levels as well as the connection with industry officials and other supporting organizations. These findings have been reported consistently with previous papers (Gou et al., 2014; Zhou et al., 2011; Li et al; 2008). The relationship is believed to facilitate FDI companies in Binh Duong to obtain sufficient legal resources. Interviewees reported three different aspects with respect to the ties with state managers: Political leaders (75\%), industry officials $(83.33 \%)$ and officials from regulatory and supporting organization (50\%). Most of the participants who discuss the political relationship mentioned these three variables.

Representatives of companies believed that the government in emerging nation such as Vietnam managed and guided economic activity by formulating plans for industrial development and establishing specific policy rules. Thus, political relations help businesses access to new policies and useful information about the industry. The finding is consistent with Guo et al., (2014). Secondly, the relationship with political leaders enhances the political legitimacy of a company or improves the extent to which officials and government agencies agreed that the operation of the company is appropriate. With the good relationship with political leaders, companies can easily win the support and have their complicated problems solved. Eighteen correspondents out of 24 interviewed companies have confirmed this opinion.

Interviewees also reported that political relations with industrial officials enable businesses to establish better access to some important resources such as getting licenses, solving land clearance, updating new regulations, and so on. In general, the stronger ties with the government, the more benefits the company receives, and this enables the company to have advantages in its own operation and management. When problems arise, the industrial officials usually provide the managers with advices and supports. In addition, the government agency allows a certain time to complete the administrative procedure. Generally, twenty representatives out of 24 interviewed companies (83.33\%) agreed that the ties with the industrial officials facilitate their working process, therefore, resulting in better performances of the whole company.

The link with administrators has helped to facilitate the administrative procedure, which FDI company usually finds difficult when investing in a new market. However, not all of FDI enterprises can create a deep relationship with the officers from supporting organization. A half of interviewed companies have complained that it is more difficult when working without strong connection to the government officials, as the company also reported long and complex administrative procedure and shortage of governmental supports. It can be concluded that the members from the regulatory, and the supporting organization played a key role in establishing smoother procedure for FDI companies.

\subsubsection{Construct 2: Institutional Support}

The study defined institutional support as the degree to which the authorities support the companies or the enterprises. According to the institutional theory, the supports of the government agency will aid in the operation of the company (North, 1990). In the emerging nation, the institutional support programs play a crucial role, especially for foreign companies or enterprises. Peng \& 
Heath (1996) also found the similar result.

Through the interview, 17 out of 24 participants talked about the Institutional support, and all of them agreed to the importance of governmental support. Although some companies satisfied with the supports offered from Binh Duong government agencies, others thought that the support should be improved to assist current FDI companies and attract prospective investors as well. The study divides the services into three groups, beneficial policies and program, useful information and local resources provision.

Interviewee 11 said that: "It is very difficult to learn the requirement of the administration department to increase the capital investment of the company. The taxes and formalities customs pose obstacles for company to engage in international trade. Last but not least, the lacks of procedure introduction, as well as complex and unclear bureaucratic procedures prevent further development in terms of capital to the company".

Based on the response, it can be assumed that the support of the government, although crucial, has not been implemented well within the case of interviewee 11. This company found it challenging to invest more capital due to the unclear and complicated policies and program. Further, the transparent procedure was not provided by the authorities.

Interviewee 14 added that: "Regarding the institutional support, laws and regulations in Vietnam have changed so fast, which make it tough for our company to keep up with the pace. Secondly, there is a shortage of logistic services, such as the low number of trucks to deliver their materials as well as their products to the customers. Thirdly, the laws are complicated, and there are too many barriers for foreigners to understand the laws. In Vietnam, there are so many authority departments, with complicated processes to run a business. Even worse, there is no guideline on the processes".

The lack of useful information (guideline), beneficial policies (simpler administrative procedures, law) and local services (logistic service) was discussed thoroughly with this interviewee. They commented that the disappointingly limited support challenged managers of the companies. He also suggested that Vietnam, firstly, should invest in transportation infrastructure, in order to improve local logistic services.

Finally, obtaining a license is much concerned. The license could be for import, technical transfers and upgrade, expansion of capital investment. However, the interviewed companies find it challenging to get the licenses. The discussions with interviewee 4 and 17 contribute to this idea.

Interviewee 4: Another problem in the administrative procedure is the obtaining of several licenses. The procedure is so complex, and it takes a long time to obtain the licenses. This would definitely damage the performances of the firm. Imagine when you need to invest more on technology to boost your production, or on imported material for high-quality products, but you cannot do so because there is no license. This obstacle will affect all business activities of a company.

Interviewee 17: What we really concern about is the necessary paperwork to obtain the license. In our opinion, there are too many required documents when applying for a business license or license to import new machines.

The negative comments of the FDI companies in Binh Duong province further convince that Institutional Supports from the government certainly improve the companies' performance and aid in their competitive advantages. Thus, this study considers the construct and following variables key determinants of FDI firm performance. 


\subsubsection{Construct 3: Administrative Procedure}

Through the interviews, this research discovers one factor that many FDI firms pay special attention on, but rarely appear on previous studies: Administrative procedure. The construct was discussed by 16 over 24 interviewed companies, embodying how important it is to them. The coding procedure divides the Administrative procedure of Binh Duong province into five distinctive variables, in accordance with special features of Binh Duong. The variable and its participants are described in the below records. Although most comments are negative, the scales are designed as inverted scales, identical to Institutional Support factor. The scales are designed so that it fit the proposition that "Better procedure improves firm performances" made in the proposed framework. Some typical complaints have been mentioned.

Interviewee 5 told us: "It is difficult for changing procedure for granting labour permit, but it is even more difficult for changing administrative procedure. The government should pay more attention to the administrative procedure so that it is more suitable to FDI firms. The procedure is so complicated and difficult to understand. This fact poses more challenges to foreign managers. We have had many problems with the administrative procedures. It is taking a certain time for the license, and the documents are rather complicated. On top of that, the pending time is just as long as the preparation time, making it even more difficult for FDI firms".

Interviewee 12 complained: The policy is difficult, and is unclear. The companies can access to the source of information, only to find out that the information is irrelevant. If we have to give suggestion, we would ask the government officials who are more qualified in order to give clear and precise guidance.

Interviewee 4 also shared his experience: The government staffs who are in charge of explaining procedures, and guidelines provide inadequate explanations when businesses contact them for information. Therefore, we do not have required info regarding different aspects of administrative procedure (tax and labour laws).

Moreover, the FDI companies in Binh Duong also seek governmental assistance in solving problems, which is discussed with interviewee 3 and 6 .

Interview 3 expressed his thought: The company plans to expand in capital, and we hope to be assisted by the government regarding the procedures. Currently, the company is investigating by itself, but since the procedure is complicated, help from the government is required to get the license quickly.

When facing problems, we come to discuss with the officials. Compared to when we first come to Binh Duong, they are more willing to help now. We really appreciate the assistance, as we can solve our problems easier, and the problems do not affect our performance as much as it used to be, as shared by Interviewee 6 .

In general, most participants state that the government did help them when they have problems. However, they are expecting to receive the better public services.

4.3.4. Construct 4: Governmental Training Activities

In previous literatures, training activities are often listed in Human Resource Management, as part of their activities. The previous studies also showed a strong positive correlation of training activities with firm performance (Terpstra \& Rozell, 1993; Russell et al., 1985). In this study, Governmental Training Activities refer to the different factors: training on several aspects offered by the government in order to help foreign companies. Based on our in-depth interviews, many company representatives viewed Governmental Training Activities as 
crucial constructs, facilitating the operations and improving the company performances. Some interviewees have recognized the governmental training activities. However, most these activities only focus on meeting the requirements of the government such as fire protection and labor safety.

The FDI companies also discussed briefly that they want to be informed of the new policies for FDI firms (the time it is implemented and the procedures) so that they can have enough time to respond and adjust their strategies. In addition, they required to be informed of the transparency of the policies and the information.

\subsection{Customers' Relationship Management}

The relationships with customers have always been the significant element in the value chain of the companies. Through the indepth interviews of several FDI companies' representatives, we find the positive link among the customer relationship, competitive advantage and firm performance. In fact, many respondents referred to the construct as one of the most important factors in the operation activities, and numerous companies choose customer-oriented approach and focus on enhancing the relationships. All interviewees who discussed having good customer relationships reported higher competitiveness and better firm's performance. We summarized some main discussions in the interviews.

Interview 2 discussed: Company managers usually organize annual meeting with significant customers. Personal talks not only help in enhancing the trust from customers, but also make important customers more willing to share their experiences.

Interview 21 and 22 also shared same personal opinions: Company directors often have meetings with the important customers. When having problems, they would like to have a direct discussion. They can easily understand, and solve the problem effectively.
Old customers trust them and become more loyal, while they have more experiences and understandings of the customers. The meeting is one of the helpful methods in gaining customers' trust.

Through these stories, it is logical to infer that meeting with significant customers as well as potential ones is an effective method in gaining trust and in understanding customers. In the world of fierce competition, gaining trust becomes increasingly important, as customers have a tendency to choose to work with their reliable partners, rather than to find new ones.

The benefits are substantial. Firstly, the higher the customers' trust, the more loyal customers would be. Secondly, the experiences from those talks will be useful in future cooperation. These benefits are likely to improve the competitive advantages and the performances of the companies.

Customer satisfaction has long been important variable that is examined in distinctive approaches in previous marketing studies. In managing the relationship with customers, satisfaction is prioritized. Higher satisfaction will enhance the relationships as well as a desire for further cooperation.

The study discovered customers' expectation and considered it as another crucial variable in analyzing relationships of customers. Through discussion with industry experts, we realize that consumers would have expectations regardless of the level of satisfaction they experienced. When they are unsatisfied with current work, they will continue to cooperate in hope of a better performance. On the other hand, they tend to have higher expectation in further collaboration for the satisfactory tasks.

Interviewee 8 said: We are conducting research to measure customers' satisfaction after each evaluation. Besides asking for customers' feedback, we compile reports and give them other related departments that are 
working directly with customers. In the feedback, we also ask for their future expectation, which acts as guidelines for later performance and cooperation.

Interviewee 13 also added that we considers understanding customers an important step in our operation. Currently, we have processes for solving customers' complaint, and we use those complaints for measuring their satisfaction and expectation. We are planning to run customer relationship department to serve our significant customers better.

The response demonstrates how important the term satisfaction and expectation means to these companies. While satisfaction can be an evaluation tool of companies' performance with a particular customer, expectations provide guidance for the companies. In the world of global integration and fierce competition, customers' power is so crucial and understanding the customers is the top priority for most companies. There is no exception for FDI firms.

Interviewees often described the customer support through the following activities: quick response to customer (interviewee 14), exceptional customer services (interviewee 8), solving customers' complaints (interviewee 13), professional care (interview 5, 6), to name a few. The companies did not go deeply into detail about such activities, so we put it into one variable. However, they emphasized that the support will enhance the relationships between customers and the companies.

In light of this fact, the customer service departments or customer relationship departments of the FDI companies always try their best to deliver active and qualified support to customers, with the prime purpose of strengthening the relationships with their current and potential customers.

\subsection{Suppliers' Relationship Management}

According to our interviews, besides customers, relationships with suppliers also contribute handsomely to the performance of the firms. Suppliers often offered several helps to the FDI companies. The main suppliers could share their knowledge and resources to the companies and offer raw material of high quality and competitive cost. The respondents also commented that having good relationships with suppliers enhances firms' performances through several ways, and this finding is consistent with previous studies (Kannan and Choon Tan, 2006).

With respect to the origin of the suppliers, only two companies that worked in the Food manufacture industry used raw material from Vietnam, especially from farmers or small and medium enterprises. However, they still complain that the supply in Vietnam is not stable, which will affect their production. Other companies working in other manufacture industries such as chemical, textile as well as electronic devices and components reported that most of their materials were imported. The material is not qualified on the grounds of their standards.

Similar to the work in customers' relationship, interviewed companies employed different approaches to improve suppliers' relationship. The responses are broken down and categorized into four variables, including a long-term relationship with main suppliers; reliable suppliers; the company's need and standards and suppliers to participate in the operations. We have discussed with participants and summarized some stories:

Interviewee 18 said: Maintaining the relationship with suppliers is beneficial in the long- run. We believe that having the relationship will help us receive raw material of better quality in time, so that we can continue our production procedure without any difficulty. It is hard to find suppliers with good quality in Vietnam.

However, interviewee 3 shared the opposite opinion: There is no need for longterm relationships with the suppliers. We are 
proactive in finding the suppliers, so if a supplier does not meet our quality standard for raw materials, we do not hesitate to find another one with higher-quality material.

Besides, interviewee 15 also quoted: I do not think long-term relationship is necessary. For example, we are facing serious problems with suppliers of vegetables, although we have worked with them in a relatively long time. The relationships do no help in this case and changing the suppliers is of our top concerns now.

The study figures out that the ease of finding suppliers depends heavily on the industry FDI companies are currently working in. The managers are working in food-related industry, and the suppliers are more available. For other cases, finding a supplier with better quality materials is challenging and long-term relationship is necessary.

The second and third activities concerned the supplier selection process. Many interviewed firms revealed that reliable suppliers with the qualified raw material are what they are looking for when choosing a main supplier. In fact, numerous companies that choose imported raw materials only because of the two criteria.

Interviewee 9 released: Raw materials are mainly imported, as the domestic suppliers do not meet our standard. However, the costs are considerably higher and affect negatively on the business performance of the company. Enterprises with foreign investment are eager to find good sources of raw materials in Vietnam and particularly, in Binh Duong Province.

Interviewee 10 revealed: Enterprises of processing industry of plastic products mostly using imported raw materials as in Vietnam, there are very few local enterprises can provide the necessary materials of high quality. 70 percent of our raw material is imported with preferential tariffs.

From these stories, the study finds out that the FDI companies value the reliable suppliers with materials that meet their standards. However, Vietnamese suppliers do not satisfy their requirements, and therefore, they have to import the raw materials to ensure the quality of the material.

\subsection{Proposed conceptual framework}

The narrative contents from the above section enable us to develop a conceptual framework for investigating the impacts of governmental management on the performance of FDI enterprises. Governmental management is a broad and vague concept, so it is divided into four constructs, all of which are measured carefully by several items. They are Managerial Political Ties, Institutional Support, Training Activities and Administrative Procedures. All constructs are expecting to have a positive effect on FDI firm performances.

As discussed above, connections with governmental officials of different kinds are beneficial to the companies in terms of governmental supports and administrative procedure. Administrative procedure of Vietnam is bureaucratic and complicated, so having the relationship is important and can become parts of firm's competitive advantages (Peng \& Luo, 2000). The link has been supported by previous studies on management of the government (Zhang \& Li, 2008; Peng \& Luo, 2000).

Institutional Supports, usually gained from the political ties, are an essential source of support that FDI firms are in urgent needs. Most of the comments on Institutional Support are negative, and the firms showed negative influences on their performances. Obviously, Institutional Support played a key role in analyzing the impact of governmental management to FDI firm performances (Gou et al., 2014).

Further, the Training Activities offered by the government are considered important by the businesses. From the descriptive contents, the government has done very well on the 
training for fire protection and labor safety. However, FDI enterprises have participated in these training activities as the compulsory requirements of the government. In fact, the training programs to introduce new law and regulations are required by numerous firms. The government did not offer proper training on such issues. Lastly, some companies reported being invited to business seminars and meetings, which they found useful and informative.

Last but not least, we recognize the main role of administrative procedures, which are the obstacles that foreign companies faced when doing business in Vietnam. This qualitative study finds some evidence that the government should help companies in their administrative procedures regarding several aspects as suggested above. The more government efficiency, transparency and accountability, the better the firm performance.

Specifically, besides the government relationship, customer and supplier relationship management also contributed to the competitive advantage and the firm performance of the companies. The two concept is added to our conceptual model as two distinctive constructs.

Thus, our conceptual framework is presented in Figure 1. Furthermore, we summarize some propositions as described in Table 2.

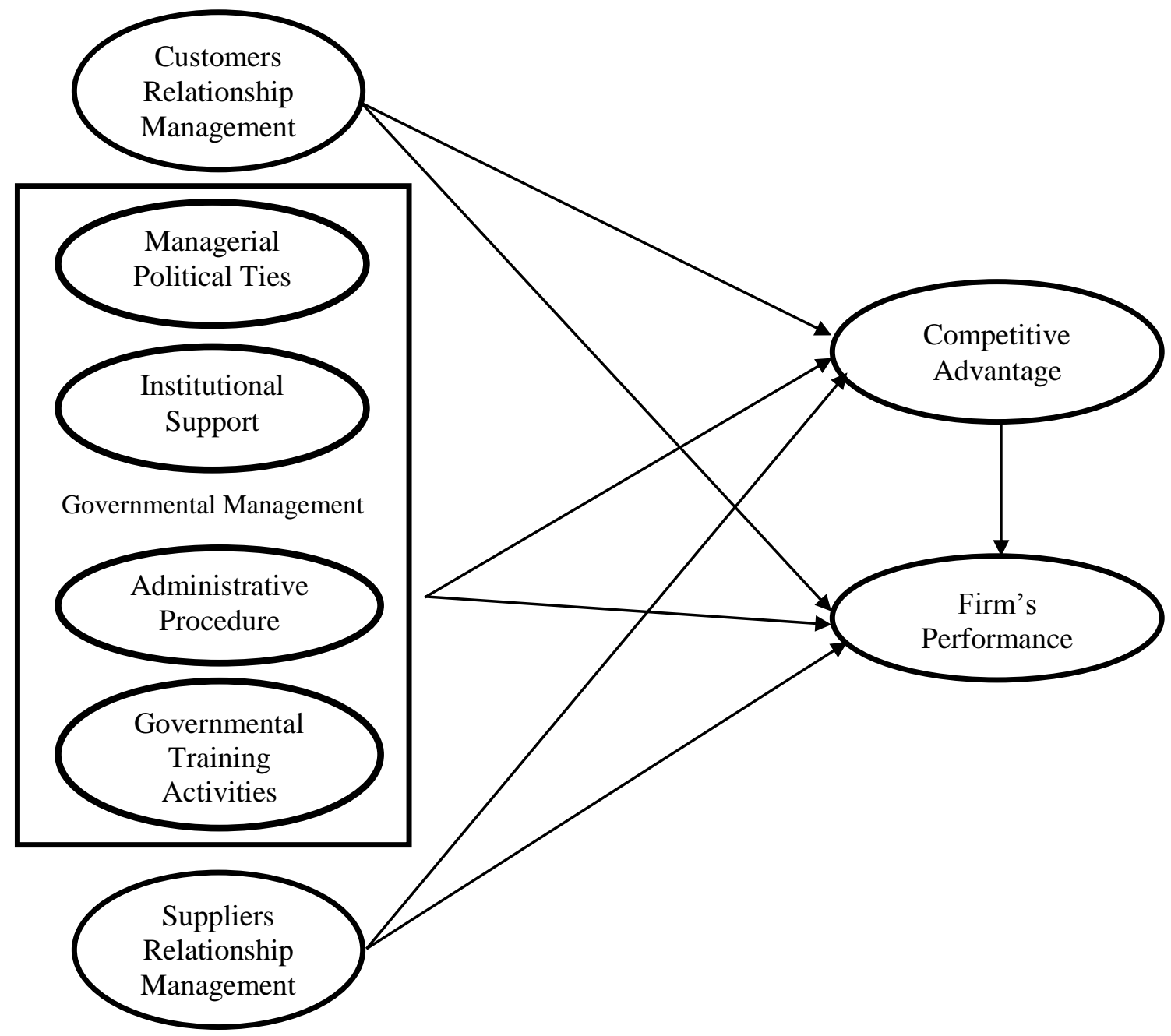

Figure 1. Conceptual Framework 


\section{Table 2. Proposing propositions in accordance with the framework}

\begin{tabular}{|l|}
\hline Proposition 1: Customers Relationship positively affects FDI firm's competitive advantage \\
\hline Proposition 2: Customers Relationship positively affects FDI firm's performances \\
\hline Proposition 3: Managerial Political Ties positively affects FDI firm's competitive advantage \\
\hline Proposition 4: Managerial Political Ties positively affects FDI firm's performances \\
\hline Proposition 5: Institutional Support positively affects FDI firm's competitive advantage \\
\hline Proposition 6: Institutional Support positively affects FDI firm's performances \\
\hline Proposition 7: Administrative Procedure positively affects FDI firm's competitive advantage \\
\hline Proposition 8: Administrative Procedure positively affects FDI firm's performances \\
\hline $\begin{array}{l}\text { Proposition 9: Governmental Training Activity positively affects FDI firm's competitive } \\
\text { advantage }\end{array}$ \\
\hline Proposition 10: Governmental Training Activity positively affects FDI firm's performances \\
\hline $\begin{array}{l}\text { Proposition 11: Supplier Relationship Management positively affects FDI firm's competitive } \\
\text { advantage }\end{array}$ \\
\hline Proposition 12: Supplier Relationship Management positively affects FDI firm's performance \\
\hline Proposition 12: Competitive Advantage positively affects FDI firm's performance \\
\hline
\end{tabular}

\section{Contribution and recommendation to other research}

The study has contributed into developing a proper framework to investigate the role of governmental management on the efficiency of business activities of FDI firms. Regarding the governmental management, most study examined the correlation of governmental management and efficiency of firm performance. However, limited number of studies has thoroughly investigated the specific roles of governmental management on firm performances. Therefore, this research concentrates on analyzing the avenues through which the management activities of the government affect FDI business performances. The conceptual framework is drawn out from the comprehensive analysis of the collected data from the qualitative study. Specifically, we discover that Managerial Political Ties, Institutional Support, Training Activities and Administrative Procedures positively correlated with FDI business performances.
In terms of managerial implications, the study gives valuable suggestions to the government of Binh Duong to improve its management and support to attract more FDI to Binh Duong. On the greater scale, the government agencies from other provinces of Vietnam that aim for industrial development should take more consideration as well.

Firstly, regarding institutional support, the government need to improve administrative procedures, which most companies find difficult in different management activities. The support is not sufficient, and most companies are still complaining about the lack of appropriate guidance. Moreover, useful information and local resources should be provided to the companies to facilitate their operations. The information can only be gotten through relationships with governmental officials. Firms without strong connection will have access to restricted information.

Secondly, Training activities for new policies for FDI firms is in urgent need. The 
government has carried out inadequate training of these latest policies, unlike that of fire protection and labor safety. Timely provision of the training will help companies to make wise decision and to take appropriate actions that will help in their performances. On top of that, the transparency of information and policies should be informed to business managers and executives.

Finally, simple and clear administrative procedures are what most companies want, according to their response in our interviews. The procedures are currently time consuming, complicated, hard-to-understand. Even worse, long procedures are preventing prospective investors to invest in Vietnam, especially in Binh Duong. Governmental agencies should consider the issue carefully and offer unflagging supports to the industry practitioners.

There are numerous potential expansions available to further researches that are worthy of consideration. Firstly, as a subsequent step to this study, future research should validate the conceptual model and give a detailed analysis of the impacts of emerging factors and their regression weights. Furthermore, future research should conduct more qualitative paper regarding new factors that affect FDI firm performances outside governmental influences. Multi-regional study should be conducted as distinctive features of each region may produce different results. Meaningful comparison drawn from these future studies would definitely enrich knowledge regarding FDI firms in Vietnam and in the world.

Acknowledgement: This research project is sponsored by the Department of Science and Technology, Binh Duong Province under grant according to the decision No 194/QĐUBND of People Committee of Binh Duong province on January 27, 2015 and the contract No. 02/HĐ-SKHCN. Any opinions, results, conclusions and recommendations expressed in this paper are those of the authors and do not necessarily reflect those of the Department of Science and Technology, Binh Duong Province.

\section{REFERENCES}

\section{Foreign research papers:}

Ahire, S. L., Golhar, D. Y., \& Waller, M. A. (1996). Development and validation of TQM implementation constructs. Decision sciences, 27(1), 23-56.

Black, S. A., \& Porter, L. J. (1996). Identification of the Critical Factors of TQM*. Decision sciences, 27(1), 1-21.

Cheung, E., Evans, E., \& Wright, S. (2010). An historical review of quality in financial reporting in Australia. Pacific Accounting Review, 22(2), 147-169.

Coltman, T., Devinney, T. M., \& Midgley, D. F. (2011). Customer relationship management and firm performance. Journal of Information Technology, 26(3), 205-219.

Ernst, H., Hoyer, W. D., Krafft, M., \& Krieger, K. (2011). Customer relationship management and company performance-the mediating role of new product performance. Journal of the Academy of Marketing Science, 39(2), 290-306.

Flynn, B. B., Schroeder, R. G., \& Sakakibara, S. (1994). A framework for quality management research and an associated measurement instrument. Journal of Operations management, 11(4), 339-366. 
Flynn, B. B., Schroeder, R. G., \& Sakakibara, S. (1995). The impact of quality management practices on performance and competitive advantage. Decision sciences, 26(5), 659-691.

Gligor, D. M., \& Autry, C. W. (2012). The role of personal relationships in facilitating supply chain communications: A qualitative study. Journal of Supply Chain Management, 48(1), 24-43.

Guo, H., Xu, E., \& Jacobs, M. (2014). Managerial political ties and firm performance during institutional transitions: An analysis of mediating mechanisms. Journal of Business Research, 67(2), 116-127.

Kannan, V. R., \& Choon Tan, K. (2006). Buyer-supplier relationships: The impact of supplier selection and buyer-supplier engagement on relationship and firm performance. International Journal of Physical Distribution \& Logistics Management, 36(10), 755-775.

Li, H., \& Zhang, Y. (2007). The role of managers' political networking and functional experience in new venture performance: Evidence from China's transition economy. Strategic Management Journal, 28(8), 791-804.

Li, H., Meng, L., Wang, Q., \& Zhou, L. A. (2008). Political connections, financing and firm performance: Evidence from Chinese private firms. Journal of development economics, 87(2), 283-299.

Mello, J., \& Flint, D. J. (2009). A refined view of grounded theory and its application to logistics research. Journal of Business Logistics, 30(1), 107-125.

Miles, M.B. and Huberman, A.M. (1994), Qualitative Data Analysis: An Expanded Sourcebook, Sage Publications, Thousand Oaks, CA.

North, C. D. (1990). Institutions, Institutional Change and Economic Performance. Cambridge, UK: Cambridge University Press.

Peng, M. W., \& Heath, P. S. (1996). The growth of the firm in planned economies in transition: Institutions, organizations, and strategic choice. Academy of management review, 21(2), 492-528.

Peng, M. W., \& Luo, Y. (2000). Managerial ties and firm performance in a transition economy: The nature of a micro-macro link. Academy of management journal, 43(3), 486-501.

Reimann, M., Schilke, O., \& Thomas, J. S. (2010). Customer relationship management and firm performance: the mediating role of business strategy. Journal of the Academy of Marketing Science, 38(3), 326-346.

Russell, J. S., Terborg, J. R., \& Powers, M. L. (1985). Organizational performance and organizational level training and support. Personnel psychology, 38(4), 849-863.

Saraph, J. V., Benson, P. G., \& Schroeder, R. G. (1989). An instrument for measuring the critical factors of quality management. Decision sciences, 20(4), 810-829.

Sheng, S., Zhou, K. Z., \& Li, J. J. (2011). The effects of business and political ties on firm performance: Evidence from China. Journal of Marketing, 75(1), 1-15. 
Soch, H., \& Sandhu, H. S. (2008). Does customer relationship management activity affect firm performance?. Global Business Review, 9(2), 189-206.

Strauss, A. \& Corbin, J. (1990). Basics of qualitative research: Grounded theory procedures and techniques. Basics of qualitative research: Grounded Theory procedures and techniques, Sage Publications, Newbury Park, CA.

Strauss, A. L. (1987). Qualitative analysis for social scientists. Cambridge University Press, New York, NY.

Terpstra, D. E., \& Rozell, E. J. (1993). The relationship of staffing practices to organizational level measures of performance. Personnel psychology, 46(1), 27-48.

Zhang, S., \& Li, X. (2008). Managerial ties, firm resources, and performance of cluster firms. Asia pacific journal of management, 25(4), 615-633.

\section{Vietnamese research papers, articles and reports:}

Binh Duong Statistics Office (2014). Binh Duong Statistics Office Report 2014.

General Statistics Office (2014). General Statistics Office Report 2014.

Hà Nam Khánh Giao \& Bùi Lê Hà (2009). Khảo sát tuân thủ các quy định về giá chuyển nhượng của các doanh nghiệp có vốn đầu tư nước ngoài tại Việt Nam. Tạp chí Phát Triển Kinh Tế, số 235 .

Hoàng Cửu Long (2009). Efforts to Attract Foreign Direct Investment to Ho Chi Minh City. Tạp chí Phát Triển Kinh Tế, số 179.

Nguyễn Minh Hà \& Bùi Quan Trọng (2012). Chuyển giá và Thuế thu nhập doanh nghiệp của Doanh nghiêp FDI tại TP HCM. Tạp chí Phát Triển Kinh Tế, số 267.

Nguyễn Quốc Nghi \& Nguyễn Hữu Thuận (2012). The Marketing Approach to FDI Attraction. Tạp chí Phát Triển Kinh Tế, số 212, 44-51.

Phạm Thế Anh \& Nguyễn Thị Hồng Đào (2013). Bounds Testing Approach to Cointegration: A Re-examination of FDI and Growth in Vietnam. Tạp chí Phát Triển Kinh Tế, số 218, 94-113.

Phạm Thị Hoàng Anh \& Lê Hà Thu (2014). Đánh giá mối quan hệ của đầu tư nước ngoài (FDI) đến sự tăng trưởng kinh tế của Việt Nam. Tạp chí Phát Triển Kinh Tế, số 220.

Sử Đình Thành \& Nguyễn Minh Tiến (2014), Impact of FDI on Provincial Economic Growth in Vietnam. Tạp chí Phát Triển Kinh Tế, số 221, 65-83. 